\title{
WIELKIE ZŁO I HEREZJE EUTYCHESA. WOKÓŁ WĄTKU PODBOJU DALMACJI W LATOPISIE POPA DUKLANINA
}

\author{
WAWRZYNIEC KOWALSKI
}

\begin{abstract}
Great sin and the heresies of Eutyches. Mysterious description of the conquest of Dalmatia in the Chronicle of the Orthodox Priest of Dioclea.

The theme of the conquest of Dalmatia by the Goths and their leaders: Totila and Ostroyllus is one of the most extensive and most important narratives within the Chronicle of the Priest of Dioclea. The article discusses the link between this theme and the Dalmatian tradition. It shows how some fragments of the medieval historiography of the region indicate that the legend of the invasion existed earlier than the Chronicle and could have been linked to the story of the assassination of the Croatian king, which we know i. a. from the Croatian version the Chronicle and from the Hungarian-Polish Chronicle. On this basis, some differences between the Latin and the Croatian versions of the Chronicle of the Priest of Dioclea are highlighted and in this context possible origins of the words about the great evil among Christians and about the Eutychian heresy have been given their possible explanation.
\end{abstract}

STRESZCZENIE. Wątek podboju Dalmacji przez wodzów Gotów: Totilę i Ostroila należy do najobszerniejszych i najważniejszych narracji w Latopisie popa Duklanina. W tym artykule omawiam związek pomiędzy tym motywem a obszerniejszą dalmacką tradycją. Staram się pokazać te fragmenty w średniowiecznej tradycji regionu, które wskazują na wcześniejsze łączenie legendy o podboju Dalmacji z opowieścią o zabójstwie chorwackiego króla znaną m. in. z chorwackiej redakcji Latopisu oraz Kroniki węgiersko-polskiej. Na tej podstawie, próbuję uwypuklić różnice w podaniowej warstwie łacińskiej i chorwackiej redakcji Latopisu, aby na ich tle spróbować wyjaśnić słowa o „wielkim grzechu wśród Chrześcijan” oraz wzmiankę o herezji eutychiańskiej, która pojawiła się tylko w jednej z wersji Latopisu.

Autor: Wawrzyniec Kowalski, Uniwersytet Wrocławski, I Instytut Historyczny, ul. Szewska 49, 50-139 Wrocław, wawrzyniec.kowalski@uwr.edu.pl, ORCID iD https://orcid.org/0000-0002-7875-9741

Słowa kluczowe: Latopis popa Duklanina, Kronika węgiersko-polska, Tomasz Archidiakon, podbój Dalmacji, Salona, Goci w tradycji średniowiecznej, król Zvonimir.

Keywords: Chronicle of the Priest of Dioclea, Hungarian-Polish Chronicle, Thomas Archdeacon, Conquest of Dalmatia, Goths in the Medieval Tradition, King Zvonimir of Croatia.

Balcanica Posnaniensia. Acta et studia, XXV, Poznań 2018, Wydawnictwo Instytutu Historii UAM, pp. 53-67, ISBN 978-83-65663-94-8, ISSN 0239-4278. Polish text with summaries in English and Polish.

doi.org/10.14746/bp.2018.25.3 
W 2018 roku minęło trzydzieści lat odkąd ukazał się polski przekład Latopisu popa Duklanina (1988). Tłumacz i redaktor tego wydania Jan Leśny (1947-1994), już na wstępie podkreślał, że ocena publikowanego utworu jest niejednoznaczna. Pisał, że w historiografii krajów słowiańskich rzadko „można spotkać dzieło równie kontrowersyjne”, za oś naukowego sporu uznając wartość źródłową tekstu. „Obok głosów niektórych historiografów - komentował Leśny - którzy widzą w nim zabytek o dużych walorach poznawczych do dziejów średniowiecznych Serbów oraz ludów i państw z nimi sąsiadujących, nie brak jednocześnie takich, którzy odmawiają mu większych wartości poznawczych, kładąc nacisk na jego tendencyjność i zmyślenia"1.

Dyskusja na temat Latopisu trwa nadal. Można wręcz stwierdzić, że przybrała na sile i dotyczy już nie tylko samej wartości źródłowej, ale też kwestii kluczowych związanych z powstaniem zabytku. W czasach Leśnego przyjmowano, że dzieło zostało napisane $\mathrm{w}$ drugiej połowie XII w., a jego autorem był anonimowy duchowny z Baru, już w szesnastowiecznej historiografii dubrownickiej określany mianem Docleaty, czyli Duklanina. Głównym celem powstania Latopisu miało być ideologiczne poparcie praw diecezji w Barze w jej sporze z biskupami Raguzy ${ }^{2}$. Tibor Živković (1966-2013) niemal dekadę temu stwierdził jednak, że część tych założeń nie wytrzymuje krytyki i, związana w dużej mierze $\mathrm{z}$ historiograficzną tradycją, nie znajduje potwierdzenia w samym tekście. Živković przekonywał, że utwór powstał pod koniec XIII lub na początku XIV w. ${ }^{3}$ Choć nie potrafił tej daty przekonująco uzasadnić, pokazał, że dotychczasowe dowody przemawiające za wczesnym datowaniem Latopisu również opierają się tylko na poszlakach. Paradoksalnie dziś na temat tego, kto i kiedy napisał to dzieło, wiemy więc mniej niż przed trzydziestu laty ${ }^{4}$.

Spróbujmy wyjaśnić, czym właściwie jest utwór zgodnie z historiograficzną tradycją nazywany Latopisem popa Duklanina. Pod tym tytułem kryje się źródło narracyjne, przedstawiające dzieje fikcyjnego słowiańskiego władztwa, jakie rozciągać się miało w średniowieczu na terenach współczesnej Chorwacji, Czarnogóry, Bośni,

1 J. Leśny, Wstęp, w: Historia Królestwa Stowian, czyli Latopis Popa Duklanina, tłum. i oprac. idem, Warszawa 1988, s. 5. [Wydanie zawiera tylko tzw. redakcję łacińską Latopisu].

2 Ibidem, s. 34-44; V. Mošin, Uvod, w: Ljetopis popa Duklanina, red. idem, Zagreb 1950, s. 11-36; F. Šišić, Uvod. O Letopisu Popa Dukljanina, w: Letopis Popa Dukljanina, red. idem, Beograd-Zagreb 1928, s. 26-47. Tam też dalsza, obszerna literatura dotycząca dyskusji o autorstwie i czasie powstania dzieła.

3 T. Živković, Gesta regum Sclavorum, Beograd 2009, t. 2, s. 373-378. Podobnie datował zabytek również Ljubomir Jovanović: O letopisu popa Dukljanina, „Godišnjak - Srpska kraljevska akademija”, 15 (1901), s. 224-225. Slavko Mijušković natomiast twierdził, że dzieło jest nawet młodsze i powstało w wieku XV: Predgovor, w: Ljetopis popa Dukljanina. Uvod, prijevod i komentar, red. idem, Beograd 1988, s. 91-93.

${ }^{4}$ Pojawiła się nawet hipoteza, że Latopis w swej łacińskiej formie byłby falsyfikatem sporządzonym przez Mauro Orbiniego na bazie starszych przekazów i spreparowanych tekstów: S. Bujan, La „, Chronique du prêtre de Dioclée”. Un faux document historique, Reveue des études Byzantines, 66 (2008), 1, s. 5-38; eadem, Orbinijevo izdanje „Ljetopisa popa Dukljanina”: povijesni falsifikat, „Radovi - Zavod za hrvatsku povijest", t. 43 (2011), s. 65-80. 
Serbii, a nawet części Albanii. Znane są dwie podstawowe redakcje tekstu: łacińska i chorwacka. Ta ostatnia, nazywana też czasem Kronika chorwacka dość wiernie powiela informacje pierwszych 23. rozdziałów redakcji łacińskiej, niektóre jej fragmenty wskazują na kontaminację tekstu, stąd też najczęściej przyjmuje się, że chorwacka wersja jest tłumaczeniem z łaciny. Nie zawiera ona wątków z okolic Dubrownika, Trawunii i Dukli, prezentuje natomiast perspektywę chorwacką. Duklaninem możemy zatem nazywać tylko anonimowego autora rozbudowanej o wątki południowej Dalmacji łacińskiej wersji. Jeśli jednak rzeczywiście napisał on swoje dzieło w Barze, w jego początkowych partiach musiał posiłkować się przekazami z północy: z Chorwacji i Splitu. Autor redakcji chorwackiej te właśnie rozdziały zdecydował się przetłumaczyć, opierając się, albo na dziele Duklanina, albo na jakimś wspólnym, niezachowanym łacińskim źródle. Warto odnotować istotną różnicę: tam, gdzie autor łacińskiej wersji posługuje się pojęciem „Słowian”, w tekście chorwackim konsekwentnie pojawiają się pochodne wyrazów „Chorwat” i „Chorwaci”. Również zakończenie redakcji chorwackiej jest zupełnie inne - utwór wieńczy rozbudowana opowieść o zabójstwie króla Zvonimira, której brak w łacińskiej wersji.

Sytuację komplikuje jeszcze sposób, w jaki zabytek przetrwał do naszych czasów. Za najstarszą uważa się redakcję łacińską, która zachowała się dwóch rękopisach (watykańskim i belgradzkim) pochodzących z połowy XVII w. Pół wieku wcześniej, włączone w 1601 r. w jego Królestwo Słowian, ukazało się włoskie tłumaczenie Mauro Orbiniego oparte na niezachowanym dziś rękopisie (lub rękopisach) różniącym się nieznacznie od wyżej wymienionych manuskryptów łacińskich. Ślady po redakcji chorwackiej ciągną się nieco dalej. Jej rękopis został najprawdopodobniej odnaleziony przez Dmine Papalicia w domu Juraja Markovicia z rodu Kačiciów ok. 1500 r. w jednej starej księdze zapisanej „pismem chorwackim”. Papalić sporządził z niej kopię, na podstawie, której Marko Marulić w 1510 r. przygotował łaciński przekład - w wieku XVI najczęściej powielaną wersję Latopisu. Jako że rękopis Papalicia zaginął, najstarszy wgląd w chorwacką lekcję tekstu zyskujemy dzięki odpisowi, jaki w 1546 r. wykonał Jerolim Kaletić. Porównując tłumaczenie Marulicia z tekstem znanym z tego manuskryptu, możemy spostrzec, że w różnią się one w kilku istotnych szczegółach i nie jest pewne, któremu z wyżej wymienionych należałoby przypisać odpowiedzialność za taki stan rzeczy. Zauważmy, że żadna znana redakcja tekstu nie jest starsza niż wiek XVI. Pierwszym niepodważalnym dowodem obecności Latopisu w obiegu literackim był prawdopodobnie dopiero fragment kroniki Adrei Dandolo z połowy XIV w., w której w bliźniaczy, co w łacińskiej redakcji Latopisu, sposób opisano podział Dalmacji ${ }^{5}$. Najwcześniejszą zaś wzmiankę o samym dziele

\footnotetext{
5 Andreae Danduli Venetorum ducis Chronicon Venetum, oprac. E. Pastorello, Rerum Italicarum Scriptores, t. 12, cz. 1, red. L. A. Muratori, Bologna 1938, s. 156. Zob. T. Živković, op. cit., s. 127. Za wcześniejszym użyciem fragmentów Latopisu w piśmiennictwie regionu przemawiają tylko pewne cechy nazewnictwa miejsc i zbieżność imion. Temat podobieństwa wybranych fragmentów Latopisu i kroniki Tomasza Archdiakona zostanie omówiony niżej.
} 
Docleaty znajdziemy dopiero w komentarzach Ludovicusa Tuberona z pierwszej połowy XVI w. ${ }^{6}$

Dzieje słowiańskiego królestwa na kartach łacińskiego Latopisu popa Duklanina rozpoczynają się w momencie inwazji. Duklanin w ten sposób zarysował jej tło:

Kiedy w mieście Konstantynopolu panował cesarz Anastazjusz, który siebie i wielu innych splamił herezjami Eutychesa, a w Rzymie zasiadał papież Gelazy, gdy w tym samym czasie jaśnieli [w wielkiej świętości] w Italii Germanus biskup i Sabin biskup Canossy oraz czcigodny mąż Benedykt na Monte Cassino, pojawił się od stron północnych naród zwany Gotami, lud dziki i nieokiełzany, którym rządzili trzej bracia, synowie jakiegoś króla Senulada o następujących imionach: pierwszy Brus, drugi Totila ${ }^{7}$, trzeci zaś Ostroil ${ }^{8}$.

Jak kontynuował dziejopis, młodsi bracia ruszyli następnie ze swymi ludźmi na południe. Wspólnie podporządkowali sobie Panonię i wkroczyli do krainy zwanej Templaną. Na wieść o tym król Dalmatyńczyków, wezwawszy na pomoc króla Istrii, ruszył Gotom naprzeciw. Chrześcijańscy władcy zatrzymali się z wojskiem w pobliżu obozu Gotów. Osiem dni trwały starcia zbrojne, ostatniego dnia stoczono krwawą bitwę. Chrześcijanie ponieśli klęskę, zginął król Istrii, a król Dalmatyńczyków uciekł do swojej siedziby w Salonie. O wyniku bitwy, jak informował dziejopis, zdecydował wyrok boży, wobec którego nikt nie odważa się zapytać, dlaczego tak jest, podpowiada on jednak, że barbarzyńcy zwyciężyli być może dlatego, ponieważ jakieś wielkie zło kryło się wśród chrześcijan ${ }^{9}$. Nie wiemy, czym było owo „ukryte zło”. Nie wiemy też, jaka mogła być funkcja wcześniejszej wzmianki o „herezjach Eutychesa”, którymi splamić się miał cesarz Anastazjusz. Oba fragmenty spełniają podobną rolę, ukazując zepsucie, które toczyło kraje chrześcijan w momencie zaatakowania ich przez

${ }^{6}$ Lvdovici Tuberonis Dalmatae abbatis Comentarii de temporibvs svis, t. 1-2, red. V. Rezar, Zagreb 2001, s.87; polski przekład: Ludwik Touberon de Crieva, Pamiętniki o czasach moich, red. P. Wróbel, J. Bonarek, Kraków 2016, s. 150-151. Zob. też: P. Wróbel, Dubrownicki benedyktyn Ludwik Tuberon De Crieva (Crijević) i jego zarys dziejów Turcji w pamiętniku politycznym "Commentarii de temporibus suis», Balcanica Poznaniensia, 21 (2014), s. 51-62.

${ }^{7}$ Formę Totila, obecną również w przekładzie Leśnego, zastosowano na określenie postaci znanej z tradycji dalmackiej. W odniesieniu do innych tradycji i historycznego wodza Gotów użyto formy Totyla.

${ }^{8}$ Historia Królestwa Stowian..., s. 61-62. Polskie tłumaczenie fragmentów Latopisu podano w przekładzie Leśnego. Pominięto jednak wprowadzone przez niego pod wpływem sugestii Šišicia emendacje, w tym wypadku zamianę imienia Senulad na Svevlad. Oryginał łaciński: Regnate in urbe Constantopolitana imperatore Anastasio, quie se et alios multos Eutychiana haeresi maculaverat, Romae vero praesiente Gelasio papa, eo tempore praeclaruerunt [multa sanctitate] in Italia Germanus episcopus et Sabinus Canusinae sedis episcopus atque venerabilis vir Benedictus apud Cassinum montem, exit quoque gens septentrionali a plaga, quae Gothi nominabantur, gens ferox et indomita, cui errant tres fraters principes, filii regis Senuladi, quorum nomina sunt haec: primus Brus, secundus Totila, tertius vero Ostroyllus, za: Ljetopis popa Dukljanina, red. V. Mošin, s. 40. [Dalej: Ljetopis... Wszystkie cytaty łacińskie i chorwackie podano według wydania Vladimira Mošina]

${ }^{9}$ Historia królestwa Stowian..., s. 62-63. Lat: et Dei iudicio, cui nemo audet dicere, cur ita faciat, quia forte aliquod magnum peccatum latebat in Christianis, za: Ljetopis..., s. 41. 
plemiona gockie. Dzięki temu Goci stają się w opisie wykonawcami bożego planu. Czy jednak te tajemnicze uwagi łączy ze sobą coś więcej? W niniejszym artykule postaram się wykazać, że nawiązanie do herezji Eutychesa nie było przypadkowe, a jego związek z grzechem wśród poddanych królów Dalmatyńczyków i Istrii mógł być silniejszy i bardziej skomplikowany, niż się początkowo wydaje.

W redakcji chorwackiej Latopisu brak jakiejkolwiek wzmianki o herezji eutychiańskiej. Nie padło w niej również imię cesarza. Pisząc o czasach gockiego najazdu, autor tej wersji wprowadza narrację zdaniem: Kraljujući cesar u gradi basiliji cesarstva ${ }^{10}$, gdzie określenie miasta mogłoby stanowić zniekształcone thumaczenie łacińskiego urbs Constantopolitana ${ }^{11}$. Choć większość różnic pomiędzy obu redakcjami należałoby zrzucić na karb podobnie niedokładnego odtworzenia tekstu przez chorwackiego tłumacza, to pewne zmiany mogły zostać wprowadzone celowo. Z redakcji chorwackiej wynika, że Goci przybyli nie z północy, lecz ze wschodu, odmiennie przedstawiono też w niej etapy najazdów Totili i Ostroila: najprvo pridosta na kraljestvo ugarsko i kralja pobiše i obujaše kraljestvo. I potom toga pojdoše naprida i pojdoše u Trnovinu ${ }^{12}$. Co ważne w kontekście dalszych rozważań, według autora tej redakcji, Totila przed uderzeniem na Dalmację pokonał węgierskiego króla i przejął władzę nad jego państwem. Kontynuował więc podbój niejako z pozycji władcy Węgier.

Warto także odnotować rolę, jaką w obu wariantach odgrywała Salona. W tekście łacińskim czytamy, że król Dalmatyńczyków miał w tym mieście swą siedzibę, a w obliczu klęski z garstka wojów zbiegt do miasta swego Salony ${ }^{13}$. Także w redakcji chorwackiej wspomniano, że kralj dalmatinski... pribivaše u čudnom i velikom gradu Solinu ${ }^{14}$. Podczas gdy z wersji łacińskiej nie dowiemy się więcej o losach dalmatyńskiego króla, z redakcji chorwackiej wynika, że kralj Dalmacije s malo vitezi smrtnom ranom ranjen ubiže $i$ bi prenešen u slavni $i$ čudni grad Solin, u kom gradu bi za veće dan općeni plač i tuga neizrečena ${ }^{15}$. Podobne wyróżnienie Salony w przywołanych wersjach podania podkreślać mógłby enigmatyczny wers zaczerpnięty z łacińskiego przekładu redakcji chorwackiej, sporządzonego przez Marulicia. W tłumaczeniu określono jednego z późniejszych królów chorwackich, Bladina, słowami Salonarum $r e x^{16}$. Tytuł ten pojawił się jednak tylko przekładzie. Jako że nie dysponujemy rękopi-

10 Ibidem, s. 40.

11 F. Šišić, op. cit., s. 423. V. Mošin, op. cit, s. 38, przyp. 3.; T. Živković, op. cit., s. 70

12 Ibidem, s. 40. W tłumaczeniu Marulicia - Tarnovia. Pojawienie się tej tajemniczej nazwy, odpowiednika Templany w redakcji łacińskiej, było przez Šišicia uznawane za zwykłą pomyłkę kopisty: op. cit., s 422-423. Živković wyjaśniał ją jako echo po zniekształconej nazwie Troi: Trinovantum: op. cit., s. 80-81. Być może Trnovinę trafniej będzie powiązać z brzmieniem jednej z lekcji Kroniki węgierskopolskiej, zob. niżej.

${ }^{13}$ Historia królestwa Stowian..., s. 63; Lat: evasit autem cum valde paucis militibus et aufugit in civitatem suam Salonam, za: Ljetopis..., 42.

14 Ibidem, s. 40.

15 Ibidem, s. 42.

${ }^{16}$ Regnvm Dalmatię atque Croatię gesta..., s. 38. Zob.: T. Živković, op. cit., s. 106. 
sem, z którego Marulić skorzystał, trudno jest ocenić, czy nie mamy w tym wypadku do czynienia ze zmianą, którą on sam wprowadził.

Wątpliwości związane z miejscem i czasem powstania Latopisu, trudność w dokładnym określeniu zależności pomiędzy jego redakcjami oraz prawdopodobna obecność niezachowanych źródeł narracyjnych, na których dziejopis zwany Duklaninem mógł oprzeć swój przekaz, każą poszukać świadectw obecności dalmackiej tradycji o grzechu chrześcijan i inwazji Gotów w innych średniowiecznych źródłach pisanych.

Opowieść o upadku Salony przekazał w połowie XIII w. Tomasz Archidiakon w dziele Historia Salonitanorum atque Spalatinorum pontificum. Co ciekawe, również on podbój Dalmacji wiązał z postacią wodza Totili i twierdził, że barbarzyńcy przybyli z północy. Okoliczności inwazji kronikarz zarysowywał następująco: Mówi się, że Salona została zniszczona w czasach Gotów, którzy pod wodza Totili opuścili krainy Teutonii i Polski ${ }^{17}$. Dalej wyjaśniał on kwestię słowiańskiego osadnictwa na ziemiach otaczających Split: Wraz z Totila przybyło z terenów Polski siedem lub osiem plemion szlachetnego pochodzenia zwanych Lingonami (Lingones). Widząc, że kraina Chorwacji nadaje się dla nich do zasiedlenia, ponieważ nieliczni mieszkańcy w niej pozostali, poprosili i otrzymali ja od swego wodza ${ }^{18}$. Przed tym opisem Tomasz kreślił wizerunek Salony, jako miasta grzechu i zepsucia, w ten sposób czyniąc z Gotów wykonawców bożej kary. Relacje Archidiakona i obu wersji Latopisu łączą więc: wspomnienie o grzechu i najeździe Gotów, jako jego następstwie, imię wodza barbarzyńców, podobieństwo trasy ich pochodu oraz rola, jaką odegrała w cytowanych narracjach Salona. Na podstawie tych zbieżności uczeni twierdzili, że Tomasz musiał znać opowieść zawartą w Latopisie ${ }^{19}$. Ferdo Šišić (1869-1940) uznał ten związek za pewny i nie wahał się nawet w swoim wydaniu źródłowym poprawić nazwę Templany na Teutonię, upodobniając szlak gockich podbojów znany z łacińskiej redakcji Latopisu do tekstu Archidiakona ${ }^{20}$. Wahania związane z datowaniem Latopisu nie pozwalają dziś jednak stwierdzić, kto ewentualnie miałby tę opowieść, od kogo zapożyczyć. Co więcej, wiele istotnych elementów obie narracje odróżnia: Duklanin nie wiedział o Lingonach, Archidiakon zaś nie wspomniał o trzech braciach, dla pierwszego opowieść o Gotach stanowiła prolog dynastycznego wywodu, w dziele drugie-

17 Gothorum tempore, qui Totila duce de partibus Teutonie et Polonie exierunt, dicitur Salona fuisse destructa, za: Thomae archidiaconi Spalatensis Historia Salonitanorum Atque Spalatinorum Pontificum/ Archdeacon Thomas of Split History of the Bishops of Salona and Split, oprac. O. Perić, red. D. Karbić, M. Matijević Sokol, J. R. Sweeney, Budapest - New York 2006, s. 34.

18 Venerant de partibus Polonie, qui Lingones appellantur, cum Totila septem vel octo tribus nobilium. Hi videntes terram Chroatie aptam sibi fore ad habitandum, quia rari in ea coloni manebant, petierunt et optinuerunt eam a duco suo, za: ibidem, s. 36. Na temat Lingonów: L. Spychała, „Lingones” Tomasza ze Splitu. Węgierska nazwa Polaków (lengyen/lengyel) czy jej poludniowosłowiański odpowiednik (Lenđel [Lenđen])?, [w:] Z badań nad historia Śląska i Europy w wiekach średnich, red. M. Goliński, S. Rosik, Wrocław2013, s. 173-215.

${ }^{19}$ Omówienie pomysłów na temat tych powiązań: Historia królestwa Stowian..., s. 26.

${ }^{20}$ F. Šišić, op. cit., s. 294, przyp. 5. 
go zaś podanie dopełniało historię upadku miasta wzorowaną na biblijnym motywie Sodomy i Gomory ${ }^{21}$. Na podstawie podobieństw obu przekazów możemy natomiast stwierdzić, że istniała jakaś dalmatyńska tradycja dotycząca upadku Salony związana z Gotami (i Totilą w szczególności), poświadczona najpóźniej w połowie XIII w., kiedy Archidiakon pisał swoją kronikę.

Wiele wskazuje na to, że właśnie nad Adriatykiem należałoby szukać korzeni podania na temat podboju Chorwacji, które przechowała Kronika wegiersko-polska ${ }^{22}$ pochodząca najprawdopodobniej z pierwszej połowy XIII w. ${ }^{23}$ Anonimowy autor opisał w niej między innymi czyny króla Węgrów Aquili, nazywanego też wcześniej Atylą ${ }^{24}$. Władcy temu ukazał się anioł, przekazując boski nakaz zemsty na poddanych, którzy w Chorwacji i Sklawonii ${ }^{25}$ podstępnie zamordowali swojego króla Kazimierza. Aquila odstępuje od zamiaru zdobycia Rzymu i wybrzeżem, przez Alpy Karynckie ${ }^{26}$, przeprowadza swoje wojska do granic Chorwacji. Tam, w trwającej osiem dni bitwie, rozprawia się z książętami Chorwacji i Sklawonii, następnie decyduje się przekroczyć Drawę i zamieszkać na urodzajnej ziemi po drugiej stronie rzeki, sam bierze za żonę córkę księcia Słowiann ${ }^{27}$, a swoich ludzi swata ze Słowiankami i Chorwatkami ${ }^{28}$.

Już Carlile Aylmer Macartney (1895-1978) zauważył, że opisy najazdu w Kronice węgiersko-polskiej i u Duklanina wyróżnia podobieństwo, które sugerowałoby, że ich autorzy korzystali z jakiejś wspólnej tradycji na ten temat ${ }^{29}$. Gdy zestawimy te przekazy, okaże się, że możemy wyróżnić trzy charakterystyczne elementy w prezentacji

\footnotetext{
${ }^{21} \mathrm{Na}$ ten temat: N. Ivić, Domišljanje prošlosti: kako je trinaestostoljetni splitski arhiđakon Toma napravio svoju salonitansku historiju, Zagreb 1992, s. 99-105.

${ }^{22} \mathrm{O}$ podobieństwie fragmentów Kroniki wegiersko-polskiej do chorwackiej redakcji Latopisu: R. Grzesik, Sources of a Story About the Murdered Croatian King in the Hungarian-Polish Chronicle, „Povijesni prilozi”, 24 (2003), s. 97-104.

${ }^{23}$ R. Grzesik, Wstęp, w: Żywot św. Stefana króla Węgier, czyli Kronika węgiersko-polska, thum. i oprac. idem, Warszawa 2003, s. 19 [dalej: Żywot...]; idem, Książę węgierski żonaty z córka Mścisława Halickiego. Przyczynek do problemu czasu i miejsca powstania Kroniki węiersko-polskiej, „Kwartalnik Historyczny", 1995, 3-4, s. 23-35. Choć datowano też kronikę na okres wcześniejszy: W. Kętrzyński, O Kronice Węgiersko-Polskiej (Vita sancti Stephani Ungaro-Polona), Rozprawy Akademii Umiejętności. Wydział historyczno-filozoficzny, Kraków 1897, s. 365-392; zob. R. Grzesik, Kronika węgiersko-polska.., s. 5-19, gdzie znajduje się streszczenie dyskusji i bogata literatura.

${ }^{24}$ Kronika węgierskopolska, oprac. S. Pilat, MPH, t. 1, wyd. A. Bielowski, Lwów 1864, s. 496.

${ }^{25}$ Pozostawiam nazwę Sclavonia w tej formie. W kontekście zaprezentowanego niżej porównania nie jest pewne, czy chodzi o Sławonię, czy o szerzej rozumiane obszary zamieszkałe przez Słowian poza właściwą Chorwacją. Zob.: R. Grzesik, (Żywot..., s. 59, przyp. 37) twierdził, że mowa jest o Sławonii, lecz przywołuje odmienną propozycję Martina Homzy postulującego szersze znaczeniu terminu.

${ }^{26}$ Znane są dwie redakcje Kroniki: dłuższa i krótsza, a ich wzajemna relacja nie jest do końca ustalona: R. Grzesik, Żywot..., s. 37-38, idem, Kronika węgiersko-polska ..., s. 21-26. W rękopisie redakcji krótszej, będą to „Alpy Tyranckie”: Dehinc prtransiuit alpes tyrancie, za: ibidem, s. 58, przyp. 34. R.Grzesik przypuszczał, że Tyrancia może być nawiązaniem do nazwy Dniestru - Tyras. Być może w tym fragmencie należałoby szukać źródeł wspomnianej już, zagadkowej Trnoviny/ Tarnovii z redakcji chorwackiej.

${ }^{27}$ Lub otrzymał od księcia Słowian córkę ,tegoż pokolenia”, zob: Żywot.., s. 60, przyp. 39.

${ }^{28}$ Ibidem, s. 56-60.

${ }^{29}$ C. A. Macartney, The Medieval Hungarian historians, Cambridge 1953, s. 178.
} 
stoczonych wtedy bitew. W każdej: walki toczyły się przez osiem dni, podkreślano, że o rezultacie starcia zdecydował sam Bóg, przedstawiono również podobne okoliczności, w jakich pokonani chrześcijanie byli łapani w niewolę.

W Kronice węgiersko-polskiej bitwę opisano następująco:

...et fecerunt conflictum magnum octo diebus: traddit autem eos Deus in manum Aquilae regis propter regnum eorum Casimirum, quem tradiderunt, et turpiter occiderunt: caesi sunt autem Sclavi et Chrvati, alii fugerunt, alii in captivitatem ducti sunt ${ }^{30}$.

Czemu odpowiadałby fragment w łacińskiej redakcji Latopisu popa Duklanina:

Octavo vero die omnes hinc inde hristiani, et gentiles, armati exierunt, et commissum est magnum proelium ab hora diei tertia, usque ad vesperam, et Dei iudicio, cui nemo audet dicere, cur ita faciat, quia forte aliquod magnum peccatum latebat in Christianis, victoriam Gothi crudeles habuerunt, ceciditque pars Christianorum et interfectus est rex Istriae, et multa milia hominum Christianorum in ore gladii mortua sunt et plurima captiva ducta sunt ${ }^{31}$.

Możemy też zacytować chorwacką redakcję Latopisu, aby przekonać się, że dwa $\mathrm{z}$ trzech elementów pozostały $\mathrm{w}$ jej brzmieniu zachowane, natomiast w miejsce branych w niewolę chrześcijan pojawiają się w tym opisie „pozabijani Chorwaci”:

I tako osmi dan krstjane i rečeni pogane oružaše se i opraviše na rečenu rvanju, i počeše boj osmi dan meju sobom, pokli se stase s jutra prija tri deri po večernjoj biše se tvrdom i nemilostivom rvanjom jednakim bojem meju sobom (...) Dali u jedan čas, tomu nitkor ne sumnjeće, nere po volji onogaj, komu nitkor ne more reći, zašto takoj učini, oni Goti nemilostivi dobiše, je da si kroz niki grih, koji tada u krstjaneh pribivaše; i prez izma bi pobijena strana krstjanska i ubijen bi kralj istri[ja] nski i mnogo tisuć krstjani po dobitju bi pod mač obraćeno i vele Hrvat bi pobijeno ${ }^{32}$.

Również podkreślenie roli stołecznego miasta zdaje się pochodzić z jednego źródła. W każdym z wymienionych przekazów naprzeciw barbarzyńców stają dwa podmioty: w jednym przypadku królowie Dalmatyńczyków i Istrii, w drugim zaś książęta Chorwacji i Sklawonii. Autor Kroniki węgiersko-polskiej nie jest zresztą pewny ilu władców Słowianie właściwie posiadali. Pisał, że Aquila, decydując się na zaślubiny, otrzymał za żonę córkę księcia Słowian (princeps Sclauorum) ${ }^{33}$. Następnie wspomniał jednak jakiegoś króla Sklawonii i Chorwacji nadmorskiej, odnotowując pod koniec opisu podboju, bez związku z resztą fabuły, że „upodobał on sobie miasto, które zwie się Splitem"34. W średniowieczu nazwę starożytnej Salony oraz zało-

${ }^{30} \mathrm{MPH}$, t. 1, s. 497 [wszystkie podkreślenia wprowadzone przez autora artykułu].

31 Ljetopis..., s. 41-42.

32 Ibidem.

${ }^{33}$ MPH, t. 1, s. 497. Lub otrzymał od niego „córkę tego [słowiańskiego] pokolenia”, Żywot..., s. 40, przyp. 39.

34 Żywot..., s. 60. W krótszej redakcji Kroniki brak tego fragmentu (ibidem, s. 60, przyp.39). Lat: Rex vero Sclavoniae et Chrvatiae circa mare delectabatur in civitate quae Sipleth dicitur, za: MPH, t. 1, s. 498. 
żonego później w ruinach pałacu Dioklecjana miasta stosowano często zamiennie ${ }^{35}$. Split pojawił się więc w tym miejscu nieprzypadkowo, byłby w kronice ekwiwalentem Salony z dzieła Duklanina. To właśnie wzmianka o Salonie kończy narrację o bitwie w obu redakcjach Latopisu. Jak już wspomniano, tam właśnie ukrył się król Dalmatyńczyków po poniesionej klęsce.

Czy węgierskiego Attylę-Aquilę z dalmackim Totylą-Totilą łączyć może coś więcej niż podobieństwo imion? Skłonność do mylenia obu dwóch postaci była w średniowieczu dość powszechna. Gotfryd z Viterbo, na przykład, nazywał Attylę wodzem Wandalów, Totylę zaś wodzem Hunów ${ }^{36}$. List Beli IV do Rzymu z 1254 r. przypominał o podbojach Totyli, w sposób, który należałoby wiązać z historycznym Attylą ${ }^{37}$. Przykłady na takie utożsamienie znajdujemy przede wszystkim we Włoszech i na Węgrzech, ale można wyszukać je poza tym obszarem. Na ziemiach polskich, na przykład, autor Kroniki wielkopolskiej twierdził, że Attylę, nazywano też Tylą ${ }^{38}$.

Badający początkowe partie Latopisu Stanoje Stanojević (1874-1937), stwierdził, że imię Totili, władcy Gotów, który pustoszył wybrzeże Adriatyku, mogło być echem tego rodzaju utożsamienia ${ }^{39}$. Podaniowego Totilę (zwłaszcza w relacji Latopisu, w mniejszym stopniu u Tomasza Archidiakona) trzeba by postrzegać jako postać, która kumulowała w sobie cechy i czyny historycznego Totyli oraz Attyli, jako legendarnego wodza Węgrów, ale też Słowian. Co ciekawe w sposób świadomy Attyli nie wiązał z Totilą sam Duklanin, który w swoim dziele wspominał ich obu: Totilę, w omawianej już sytuacji podboju ziem nadadriatyckich, oraz nieco dalej Attylę, węgierskiego władcę, którego odparł słowiański król Tomislav ${ }^{40}$.

Zarówno w opowieści zawartej w Kronice węgiersko-polskiej, jak i w obu redakcjach Latopisu zwycięstwo najeźdźców było wynikiem grzechu najechanych, jednak

${ }^{35}$ M. Matijević Sokol, Toma Arhiđakon i njegovo djelo, Split 2002, s. 231 i n; L. Kunčević, Mit o Dubrovniku. Diskursi identiteta renesansnog grada, Zagreb Dubrovnik 2015, s. 75 i n., tam również o podobnych procesach przejmowania (i konstruowania) przez średniowieczne miasta dalmackie tradycji antycznych.

${ }^{36}$ Thotila rex Hunnorum, sive Athila rex Wandalorum Belam germanum ... peremit, za:Gotifredi Vitebiensis Speculum regum, red. G. Waitz, MGH SS, t. XXII, ed. G. H. Pertz, Hannoverae 1872, s. 85. Zob. również: Quellen und Forschungen zur ältesten Geschichte der Stadt Florenz, wyd. O. Hartwig, cz. 1, Marburg 1875, s. XVII-XVIII. Otto Hartwig omawia przykłady utożsamienia dwóch barbarzyńskich wodzów i konsekwencje tego zjawiska w ramach tradycji florenckiej.

${ }^{37}$ Totila in exemplum veniat, qui ex parte Orientis ad Occidentem veniens subiugandam, in medio regni Hungariae sede suam principaliter collocauit, za: Codex diplomaticus Hungariae ecclesiasticus ac civilis, red. G. Feyé, t. IV., cz. 2., Budae 1829, s. 222.

${ }^{38}$ Chronica Poloniae maioris, s. 7. Za: B. Kürbis, Wstęp, w: Kronika Wielkopolska, tłum. K. Abgarowicz, Krakow 1965, s. 44, przyp. 25. Kürbis omawia rolę, jaką w upowszechnieniu się motywu odegrał Marcin z Opawy. O fabularnych powiązaniach Attyli i Słowian w średniowiecznym dziejopisarstwie zob.: R. Grzesik, Attyla a Stowianie. Przyczynek do wyobrażeń o kontaktach huńsko-stowiańskich w średniowiecznych źródłach narracyjnych, „Roczniki Historyczne”, 59 (1993), s. 33-42.

${ }^{39}$ S. Stanojević, O prvim glavama Dukljanskog Letopisa, „Glas - Srpska kraljevska akademija. Drugi razred", 126 (1927), s. 93-101.

${ }^{40}$ Ljetopis..., s. 58. 
tylko opowieść o podbojach Aquili jest w tym względzie spójna i nie ukrywa natury przewinienia - według kronikarza miało nim być królobójstwo. Sekwencja zdarzeń prezentuje się więc następująco:

1. Panujący w Chorwacji i Sklawonii król Kazimierz zostaje zamordowany przez własnych poddanych

2. Bóg wysyła Aquilę, jako wykonawcę swej woli, by pomścił Kazimierza

3. Rozgrywa się trwająca osiem dni bitwa, książęta Chorwacji i Sklawonii zostają pokonani

4. Aquila żeni się z córką księcia Słowian, swoich ludzi zaślubia ze Słowiankami i Chorwatkami

5. Król Sklawonii i Chorwacji nadmorskiej obiera Split za swą siedzibę

Porządek zdarzeń w obu redakcjach Latopisu prezentuje się odmiennie, mimo podobieństwa opisu bitwy, kilka wątków (np. zaślubiny) w ogóle się w nich nie pojawia. Z żadnej nie dowiadujemy się też wprost, czym był grzech, który zdecydował o zwycięstwie Gotów. W tym kontekście redakcja chorwacka wyraźnie się jednak od łacińskiej różni - podobnie jak Kronika węgiersko-polska zawiera ona opowieść o zabójstwie chorwackiego króla. Nie był nim jednak Kazimierz, lecz Zvonimir, a legenda o jego śmierci stanowi zwieńczenie tej wersji Latopisu.

$\mathrm{Na}$ temat powiązań między Kronika węgiersko-polska, a chorwacką wersją Latopisu popa Duklanina pisano już wcześniej ${ }^{41}$. Przypuszcza się, że tradycja o królobójstwie mogła trafić na teren Węgier właśnie z Chorwacji. Możliwe, że imię Kazimierz pojawiło się w tekście, zastępując imię jakiegoś lokalnego władcy, którym mógł być Krešimir ${ }^{42}$. Brygida Kürbis uznała, że wpływ taką zmianę w narracji Kroniki węgiersko-polskiej wywarła polska tradycja o Kazimierzu Odnowicielu ${ }^{43}$.

Podanie o śmierci Kazimierza, które przechowała kronika, byłoby najstarszym zachowanym śladem kształtowania się tradycji o zabójstwie chorwackiego władcy przez własnych poddanych. W pozostałych wariantach wątek ten był związany z postacią króla Zvonimira, przez średniowieczną historiografię chorwacką często niesłusznie uważanego za ostatniego ,rodzimego" władcę ${ }^{44}$. Pochodząca prawdopodobnie z XIV

${ }^{41}$ Zob.: R. Grzesik, Kronika wegiersko-polska..., s. 82-90; idem, Sources of a Story About the Murdered Croatian King... - tam dalsza literatura przedmiotu.

${ }^{42}$ Ibidem, s. 83-84. Brygida Kürbis uznała, że wpływ na taką zmianę w narracji Kroniki węgiersko-polskiej wywarła polska tradycja o Kazimierzowi Odnowicielu: B. Kürbis, Studia nad „Kronika wielkopolska", Poznań 1952, s. 140-141. Śladem tego procesu może być specyficzna forma w redakcji krótszej dzieła, gdzie miano trezimir należałoby identyfikować właśnie z Krešimirem.

43 Ibidem.

${ }^{44}$ Przegląd literatury związanej z tematem m. in.: D. Nemet, Smrt hrvatskog kralja Zvonimira problem, izvori i tumačenja, „Radovi Zavoda za hrvatsku povijest Filozofskoga fakulteta Sveučilišta u Zagrebu", (41) 2009, 1, s. 73-92; J. Bratulić, Legenda o kralju Zvonimiru, w: Zvonimir - kralj hrvastki. Zbornik radova, red. I. Goldstein, Zagreb 1997, s. 235-241; M. Drmač, Legenda o Zvonimirovoj smr$t i$, „Motrišta. Časopis za kulturu, znanost i društvena pitanja”, 2012, 64-65, s. 124-138; S. Gunjača, Uz 
lub XV w. chorwacka redakcja Latopisu popa Duklanina jest prawdopodobnie pierwszym znanym utworem, który łączył motyw królobójstwa właśnie ze Zvonimirem. Podobna opowieść została zanotowana w anonimowej Kronice splickiej datowanej nawet na wiek XIV ${ }^{45}$, w kontynuacji kroniki Tomasza Archidiakona, znanej jako Historia Salonitana maior ${ }^{46}$, prawdopodobnie z początku XVI w. i w Chronicon breve regni Croatie Ivana Tomašicia $\mathrm{z}$ drugiej połowy tegoż wieku ${ }^{47}$.

$\mathrm{W}$ każdej z wymienionych realizacji wątku śmierci Zvonimira pojawiały się wspólne elementy: motyw krucjaty, której niechętni byli poddani władcy, podobny schemat zabójstwa króla czy następująca po nim węgierska interwencja. Podanie w tej formie stanowić mogło zamkniętą całość i w przeciwieństwie do wzmianki Kroniki węgiersko-polskiej nie było łączone z wątkiem inwazji barbarzyńców na Chorwację i Dalmację. Opowieść o Zvonimirze, wieńcząca chorwacką wersję Latopisu, również stanowi zwarty, wyróżniając się w obrębie całości wątek, lecz, co zagadkowe, także wcześniejsze fragmenty tej redakcji charakteryzuje pewne podobieństwo do wybranych elementów opowieści o zemście Aquili w Kronice węgiersko-polskiej: osiem dni walki, Salona, jako stolicę króla Dalmacji oraz ukryty po stronie chrześcijan grzech. Możliwe, że choć następstwo zdarzeń uległo w tekście redakcji chorwackiej zakłóceniu, to końcowy opis zabójstwa Zvonimira, stanowił właśnie wytłumaczenie kary, która na Chorwatów spadła.

Ryszard Grzesik zauważył, że skąpą charakterystykę przejęcia kraju przez Węgrów po śmierci Zvonimira w omawianej redakcji Latopisu cechuje zbieżność z opisem Kroniki wegiersko - polskiej, w którym uzasadniano najazd Aquili ${ }^{48}$. Wersy: I imiše kralja Belu za gospodina, jere svoga biše ubihu prez krivine, i po rečenom kralju ugarskomu Hrvati biše podloženi od volje u nevolju ${ }^{49}$, odpowiadałby słowom: tradidit autem eos Deus in manus Aquilae regis proptem eorum Casimirum, quem tradiderunt, et turpitem occiderunt ${ }^{50}$.

Czy znajdziemy między obu tekstami więcej tego typu podobieństw? Jak wspomniał autor Kroniki węgiersko-polskiej: ci, którzy zdradziecko zabili króla Kazimierza,

novi izvor o smrti kralja Zvonimira, „Mogućnosti”, 1961, 2, s. 161; S. Gunjača, Kako i gdje je završio hrvatski kralj Dimitrije Zvonimir, s dodatkom: O grobu kralja Zvonimira na Kapitolu kod Knina, „Rad Jugoslovenske akademije znanosti i umjetnosti”, 288 (1952), s. 205-324; idem, Uz novi izvor o smrti kralja Zvonimira, „Mogućnosti”,1961, 2, s. 158-165; H. Morović, Novi izvori o nasilnoj smrti kralja Dimitrija Zvonimira, „Mogućnosti”, 1960, 10, s. 830-838,

${ }^{45}$ M. Kurelac, Povijesni zapis nazvan «Anonimna Kronika» u rękopisu Naučne biblioteke u Zadru, «Historijski zbornik», 23-24 (1970-71), s. 363-374. Omówienie framentu poswięconego śmierci Zvonimira D. Nemet, op. cit., s. 81-82.

${ }^{46}$ Historia Salonitana maior, oprac. N. Klaić, red. J. Tadić, Beograd 1967, s. 110-112.

${ }^{47}$ Fragment za: Izvori za hrvatsku povijest do 1526. godine, oprac. N. Klaić, Zagreb 1972, s. 75; D. Nemet, op. cit., s. 82-83. Władca nosi w niej imię Zorobel, co stanowić by mogło ślad wpływu źródeł węgierskich.

${ }^{48}$ R. Grzesik, Kronika wegiersko-polska, s. 89.

${ }^{49}$ Ljetopis..., s. 68.

${ }^{50} \mathrm{MPH}$, t. 1., s. 497. 
uzasadniali swój czyn słowami: „Żaden król nigdy nie będzie [panował] nad nami, lecz sami będziemy się rządzić" 51 . W chorwackiej redakcji Latopisu przewrotne podobieństwo do tych słów wykazuje klątwa umierającego Zvonimira, aby „niewierni Chorwaci” nigdy już „nie mieli pana mówiącego ich językiem, ale podlegali obcej mowie" 52 . Autor tej narracji wspomina zresztą wielokrotnie o tej negatywnej cesze Chorwatów, która nie pozwalała im docenić dobrego władcy. W czasie opisu buntu Seislava przeciwko własnemu ojcu, Radoslavowi, pisał, że wraz z uzurpatorem przewrotu dokonali „niewierni Chorwaci”, którzy vazda su bolji bili prid strahom i pitomiji pod silom, nere vladani dobrotom dobrimi ${ }^{53}$. Do tych wydarzeń nawiązał później opisując okoliczności śmierci Zvonimira, nazywając Chorwatów przeklętymi przez Boga i (znów) niewiernymi ${ }^{54}$. Dziejopis twierdził też, że dobry król Zvonimir nie jest dla Chorwatów zašto oni ne će biti dobrotom dobiti, da, bolji su pod strahom ${ }^{55}$.

Uzbrojeni w wiedzę na temat przypisywanych Chorwatom cech, wróćmy raz jeszcze do opisu bitwy stoczonej przez chrześcijan z Gotami. Zauważmy, że w wariancie chorwackim nie jest jasne, po której stronie stanęli Chorwaci. W łacińskiej redakcji Latopisu Goci, którzy podbili Dalmację, osiedlają się w niej i w pewnym momencie stają się Słowianami. Zdanie: Id est Gothi, qui et Sclavi ${ }^{56}$ pojawiło się przy opisie panowania króla Bladina i od tego momentu Goci znikają z kart łacińskiego tekstu. Formuły tej brakuje jednak w lekcji chorwackiej, nie jest więc powiedziane, że autor tej wersji uznawał Chorwatów za potomków Gotów. Co więcej tłumaczenie łacińskiego: et multa milia hominum Christianorum in ore gladii mortua sunt et plurima captiva ducta sunt ${ }^{57}$, które pojawia się w opisie bitwy, przełożono jako: i mnogo tisuć krstjani po dobitju bi pod mač obraćeno i vele Hrvat bi pobijeno ${ }^{58}$, co sugeruje, że w drugim z przywołanych cytatów Chorwaci mogli występować w walce po chrześcijańskiej stronie. Wyjaśniałoby to naturę grzechu, który w czasie bitwy krył się wśród przegrywających. Byłby on związany z tymi cechami charakteru Chorwatów, które w tekście chorwackiej redakcji dadzą o sobie znać jeszcze kilkukrotnie. Pomimo zaburzenia sekwencji zdarzeń, początkowy najazd i końcowe przejęcie władzy przez Belę I, który wkroczył do Chorwacji, by pomścić Zvonimira, są ze sobą połączone jako powtórzenie tej samej historii, którą najkonsekwentniej realizował autor Kroniki węgiersko-polskiej.

51 Żywot..., s. 57. Lat: nunquam rex erit super nos, sed nos ipsi regnabimus, za: MPH, t. 1, s. 497.

52 ...prokle tadaj nevirne Hrvate i ostatak njih bogom i svetimi njegovimi, $i$ sobom, i nedostojnom smrtju njegovom, $i$ da bi veće Hrvati nigdar ne imali gospodina od svoga jazika, nego vazda tuju jaziku podložni bili, za: Ljetopis..., s. 62.

53 ... i progna [Seislav] dobroga kralja oca svoga s nevirnimi Hrvati, koji vazda su bolji bili prid strahom i pitomiji pod silom, nere vladani dobrotom dobrimi, za: ibidem, s. 67.

54 ...bogom prokleti i nevirni Hrvati ki ne mnoga prija daše pomoć hudobnomu sinu dobroga njih gospodina Radoslava iz kraljestva njegova izgnati, za: ibidem.

55 Ibidem.

${ }^{56}$ Ibidem, s. 46.

57 Ibidem, s. 42.

${ }^{58}$ Ibidem. 
Inaczej w redakcji łacińskiej, gdzie brak podania o Zvonimirze. Pojawia się w niej co prawda historia zamordowanego króla Vladimira, okoliczności jego śmierci są jednak zupełnie inne, a sam motyw nie daje się w żaden sposób powiązać z omawianym zestawem wątków. Jak już wspomniano, ekwiwalentem Chorwatów w redakcji łacińskiej Latopisu są Słowianie, ci zaś byli potomkami Gotów, nie byli więc obarczeni grzechem, który zadecydował o przebiegu rozstrzygającej bitwy. Duklanin nigdy nie przedstawiał Słowian w tak negatywnym świetle, w jakim kilkukrotnie stawiał Chorwatów autor chorwackiej redakcji. W przeciwieństwie do niego Duklanin nie pisał swej historii, by pokazać dzieje upadku rodzimego królestwa. Nie jest więc wykluczone, że imię cesarza Anastazjusza i nawiązanie do herezji Eutychesa, którą „splamił siebie i innych”, weszło w obręb tej opowieści, właśnie po to, by wytłumaczyć fragment, w którym mowa jest o grzechu chrześcijan. Ta ostatnia wzmianka stanowiła ważny element tradycji o najeździe Totili na Chorwację i Dalmację. Duklanin powielił ją, opierając się na jakimś chorwackim przekazie, pisząc jednak w rejonie oddalonym od miejsca, w którym opowieść się kształtowała. Sprawy chorwackie nie stanowiły dla niego głównego przedmiotu zainteresowań, dostosował wiec historię do pragmatycznych celów własnej narracji, opiewającej dzieje słowiańskiego królestwa. Przenosił jego geograficzną lokalizację z północy, z Chorwacji, stopniowo na południe, do Trawunii, Dukli i w okolice Dubrownika. Historia podbojów Totili i jego brata, mogła być dla niego i jego czytelników niejasna, dlatego we wstępie sam dziejopis lub jakiś późniejszy interpolator dodał wzmiankę o herezji cesarza, która skazić mogła również chrześcijańskich królów Dalmatyńczyków i Istrii, jak wynika z opisu późniejszych wydarzeń będących do pewnego stopnia cesarskimi sojusznikami lub poddanymi. Jeśli przyjmiemy, że chorwacka redakcja stanowiła tłumaczenie tekstu łacińskiego Latopisu, lub jakiegoś wspólnego nieznanego źródła, które w przybliżeniu odpowiadałoby pierwszym 23. rozdziałom łacińskiej redakcji, wyjaśniałoby to również, dlaczego u znającego lepiej tradycję chorwackiego translatora brak wzmianki o Eutychesie, pojawił się natomiast (lub został zachowany) motyw zabójstwa Zvonimira jako wątek z związany z bitwą, grzechem i historią upadku chorwackiego królestwa.

\section{BIBLIOGRAFIA}

Latopis popa Duklanina (wszystkie redakcje): Historia Królestwa Stowian, czyli Latopis Popa Duklanina, tłum. i oprac. J. Leśny, Warszawa 1988. Letopis Popa Dukljanina, red. F. Šišić, Beograd-Zagreb 1928. Ljetopis popa Duklanina, red. V. Mošin, Zagreb 1950. Ljetopis popa Dukljanina. Uvod, prijevod i komentar, red. S. Mijušković, Beograd 1988. Regnvm Delmatię atque Croatię Gesta a Marco Marvlo Spalatensi Patritio Latinitate Donata, red. N. Jovanović, "Colloquia Maruliana", 18 (2009), s. 28-61. 


\section{Inne źródla:}

Andreae Danduli Venetorum ducis Chronicon Venetum, oprac. E. Pastorello, Rerum Italicarum Scriptores, t. 12, cz. 1, red. L. A. Muratori, Bologna 1938.

Codex diplomaticus Hungariae ecclesiasticus ac civilis, red. G. Feyé, t. 4, cz. 2., Budae 1829.

Chronica Poloniae maioris, red. Brigida Kürbis, MPH series nova, t. 8, Warszawa 1970.

Gotifredi Vitebiensis Speculum regum, red. G. Waitz, MGH SS, t. 22, ed. G. H. Pertz, Hannoverae 1872.

Historia Salonitana maior, oprac. N. Klaić, red. J. Tadić, Beograd 1967.

Izvori za hrvatsku povijest do 1526. godine, oprac. N. Klaić, Zagreb 1972.

Kronika węgierskopolska, oprac. S. Pilat, MPH, t. 1, wyd. A. Bielowski, Lwów 1864, s. 485-515.

Kronika Wielkopolska, oprac. B. Kürbis, tłum. K. Abgarowicz, Kraków 1965.

Lvdovici Tvberonis Dalmatae abbatis Comentarii de temporibvs svis, t. 1-2, red. V. Rezar, Zagreb 2001.

Ludwik Touberon de Crieva, Pamiętniki o czasach moich, red. i tłum. P. Wróbel, J. Bonarek, Kraków 2016.

Quellen und Forschungen zur ältesten Geschichte der Stadt Florenz, wyd. O. Hartwig, cz. 1, Marburg 1875.

Thomae archidiaconi Spalatensis Historia Salonitanorum Atque Spalatinorum Pontificum/Archdeacon Thomas of Split History of the Bishops of Salona and Split, oprac. O. Perić, red. D. Karbić, M. Matijević Sokol, J. R. Sweeney, Budapest - New York 2006.

Żywot św. Stefana króla Węgier, czyli Kronika węgiersko-polska, tłum. i oprac. R. Grzesik, Warszawa 2003.

\section{Literatura:}

Bratulić Josip, Legenda o kralju Zvonimiru, w: Zvonimir - kralj hrvastki. Zbornik radova, red. I. Goldstein, Zagreb 1997, s. 235-241.

Bujan Solange, La "Chronique du prêtre de Dioclée”. Un faux document historique, "Reveue des études Byzantines”, 66 (2008), 1, s. 5-38.

Bujan Solange, Orbinijevo izdanje "Ljetopisa popa Dukljanina": povijesni falsifikat, "Radovi - Zavod za hrvatsku povijest”, 43 (2011), s. 65-80.

Drmač Marjan, Legenda o Zvonimirovoj smrti, "Motrišta. Časopis za kulturu, znanost i društvena pitanja”, 2012, 64-65, s. 124-138.

Grzesik Ryszard, Attyla a Słowianie. Przyczynek do wyobrażeń o kontaktach huńsko-słowiańskich w średniowiecznych źródłach narracyjnych, ,Roczniki Historyczne”, 59 (1993), s. 33-42.

Grzesik Ryszard, Kronika węiersko-polska, Poznań 1999.

Grzesik Ryszard, Książę węgierski żonaty z córka Mścisława Halickiego. Przyczynek do problemu czasu i miejsca powstania Kroniki węgiersko-polskiej, „Kwartalnik Historyczny”,102 (1995), 3-4, s. 2335.

Grzesik Ryszard, Sources of a Story About the Murdered Croatian King in the Hungarian-Polish Chronicle, "Povijesni prilozi", 24 (2003), s. 97-104.

Gunjača Stjepan, Kako i gdje je završio hrvatski kralj Dimitrije Zvonimir, s dodatkom: O grobu kralja Zvonimira na Kapitolu kod Knina, "Rad Jugoslovenske akademije znanosti i umjetnosti", 288 (1952), s. 205-324.

Gunjača Stjepan, Uz novi izvor o smrti kralja Zvonimira, “Mogućnosti”,1961, 2, s. 158-165.

Kętrzyński Wojciech, O Kronice Węgiersko-Polskiej (Vita sancti Stephani Ungaro-Polona), „Rozprawy Akademii Umiejętności. Wydział historyczno-filozoficzny”, Kraków 1897.

Kunčević Lovro, Mit o Dubrovniku. Diskursi identiteta renesansnog grada, Zagreb -Dubrovnik 2015.

Kurelac Miroslav, Povijesni zapis nazvan «Anonimna Kronika» u rukopisu Naučne biblioteke u Zadru, «Historijski zbornik», 23-24 (1970-71), s. 363-374.

Ivić Nenad, Domišljanje prošlosti: kako je trinaestostoljetni splitski arhiđakon Toma napravio svoju salonitansku historiju, Zagreb 1992.

Jovanović Ljubomir, O letopisu popa Dukljanina, „Godišnjak - Srpska kraljevska akademija”, 15 (1901), s. $220-226$. 
Macartney Carlile Aylmer, The Medieval Hungarian historians, Cambridge 1953.

Matijević Sokol Mirjana, Toma Arhiđakon i njegovo djelo, Split 2002.

Morović Hrvoje, Novi izvori o nasilnoj smrti kralja Dimitrija Zvonimira, "Mogućnosti”, 7 (1960), 10, s. $830-838$.

Nemet Dražen, Smrt hrvatskog kralja Zvonimira - problem, izvori i tumačenja, "Radovi Zavoda za hrvatsku povijest Filozofskoga fakulteta Sveučilišta u Zagrebu", (41) 2009, 1, s. 73-92.

Spychała Lesław, „Lingones” Tomasza ze Splitu. Węgierska nazwa Polaków (lengyen/lengyel) czy jej potudniowostowiański odpowiednik (Lenđel [Lenđen])?, [w:] Z badań nad historia Ślaska i Europy w wiekach średnich, red. M. Goliński, S. Rosik, Wrocław2013, s. 173-215.

Stanojević Stanoje, O prvim glavama Dukljanskog Letopisa, „Glas - Srpska kraljevska akademija. Drugi razred", 126 (1927).

Wróbel Piotr, Dubrownicki benedyktyn Ludwik Tuberon De Crieva (Crijević) i jego zarys dziejów Turcji w pamiętniku politycznym «Commentarii de temporibus suis», «Balcanica Poznaniensia», 21 (2014), s. $51-62$.

Živković Tibor, Gesta regum Sclavorum, t. 2, Beograd 2009. 
